\title{
APPLICATION ON THE WORKPLACES HAZARDS MEASUREMENT IN A BAKERY UNIT
}

\author{
MIRELA PANAINTE-LEHADUS ${ }^{1 *}$, NARCIS BARSAN ${ }^{1}$, OANA IRIMIA ${ }^{1}$, \\ CLAUDIA TOMOZEI ${ }^{1}$, EMILIAN MOSNEGUTU ${ }^{1}$, FLORIN NEDEFF $^{1}$, \\ ${ }^{1}$ Department of Environmental Engineering and Mechanical Engineering, "Vasile \\ Alecsandri" University of Bacau, Street Marasesti 157, Bacau, Romania
}

\begin{abstract}
The workplaces, where human activity takes place, is characterized by some complex factors that can affect the health of employees. These factors (temperature, humidity, noise, vibration, toxic substances, lighting, particulate matter etc.) can also be generalized as dangerous factors or workplaces hazards [1, 2, 3, 4]. In this article are presented some results obtained after workplaces hazards measurements in a production and sales bakery unit for the parameters: $\mathrm{O}_{2}, \mathrm{SO}_{2}, \mathrm{CO}, \mathrm{NH}_{3}$, temperature, humidity, suspension powders, VOC. The values of the measured parameters particulate matter $\left(0.17 \mathrm{mg} / \mathrm{m}^{3}-0.30\right.$ $\left.\mathrm{mg} / \mathrm{m}^{3}\right)$ respectively volatile organic compounds $(0.8 \mathrm{ppm} \div 21.1 \mathrm{ppm})$ were below the maximum allowable concentrations, which indicates a safe workplaces for employees. The other parameters measured values, respectively temperature and humidity, were between $22.10^{\circ} \mathrm{C}-29.20^{\circ} \mathrm{C}$ for temperature and $47 \%-53 \%$ for humidity.
\end{abstract}

Keywords: workplaces hazards, particulate matter, volatile organic compounds, temperature, humidity

\section{INTRODUCTION}

The incidence of work accidents in the industrial sector raises the issue of the effectiveness of health and safety policies at workplaces. In general, the major accidents are rare. The technologies involved in any hazardous process are grounded to reduce the accident probability. At the beginning of the industrial revolution, accidents were considered inevitable. The legislative regulations in the field have forced those responsible for these processes to improve safety at work $[5,6]$.

In the last period, new processes and equipment have been constantly developed to satisfy the society consumption needs. Typical, the workers with such equipment must have operational knowledge to ensure a proper operation and to perform high products quality. When this knowledge is reduced, the workplace accidents are increase. The knowledge lack can have several causes $[5,6]$ :

- new technologies;

- loss of knowledge due to inadequate training, procedures or information;

- inability to accumulate new knowledge.

New technologies are vital to global development and living conditions improved. However, when dangerous processes are involved (chemical, petrochemical, petroleum and gas industries, nuclear power plants, etc.), we must pay attention to the risks that may arise $[5,6]$.

\footnotetext{
${ }^{*}$ Corresponding author, email: mirelap@ub.ro

(C) 2017 Alma Mater Publishing House
} 
The conditions and organization of the workplace are factors that contribute to the work accidents. Thus, labor safety requires that working conditions do not create significant risks for workers. Workplace health and safety aims to create conditions, capabilities and habits that enable the worker to work effectively [7].

The studies on labor health and safety focused on preventing wastage, ergonomic aspects, hygiene conditions or temperature and noise $[7,8,9]$.

It also analyzed the influence of stress on workers' health, becoming a phenomenon frequently related to workplace activities. Exposure to noise, work with hazardous materials, heavy physical requirements (rapid labor, high demands for labor, low social support at the workplace are other causes leading to labor accidents) [7, 8, 9].

The intoxications is one of the health problems that can be prevented around the world. Carbon monoxide is one of many contaminants present in the environment and responsible for a high percentage of accidental intoxications or deaths reported worldwide every year [10].

The toxic emissions, particulate matter, can have irreversible effects on human health and can be found in workplaces [11]. Also, the toxic emissions are a serious problem regard work safety. In the case of particulate matter, these can migrate from the raw materials into the atmosphere and working enclosure. In a study by Rim and Novoselac it is shown that when the pollutant source is located close to the soil level, the particle concentration inhaled by the workers in that workplace was four times higher than the admissible [12]. Other research in the field present that PM 2.5 a concentration evaluation in five food preparation activities were to 9 times higher than the accepted normal concentrations [11].

The present paper aims to evaluate the noxiousness level to which the workers are exposed in a bakery production and sales unit.

\section{METHODOLOGY AND RESULTS}

The measurements were carried out at S.C. Nedenka S.R.L. Bacau, the company has as a working profile the bakery products production and sale. The measurements were aimed at determining the occupational harm at the work point. The measurements were carried out on October 9, 2015 and aimed to determine the following parameters: $\mathrm{O}_{2}, \mathrm{SO}_{2}, \mathrm{CO}, \mathrm{NH}_{3}$, temperature, humidity, suspension powders, VOC. The measurements were carried out in 3 unit work points (Figures 1a and 1b): raw materials warehouse, bakery products production and sale, production and sale of pastry products. Only the technological elements that can influence by using / operating the quality of the environment in the enclosure were represented in the schemes. Their positioning can be changed according to the particularities of the technological process and its transformation.

The following measuring devices were used to perform the measurements: MICRODUST PRO CEL-712 analyzer, Alphaix 3000 analyzer for determination of emissions from different working environments, Thermo-hygrometer for determination of atmospheric humidity and ambient temperature.

Regarding the values obtained for the measured parameters, for the parameter $\mathrm{CO}, \mathrm{NO}, \mathrm{NH} 3$ the measured value is zero. The oxygen volume recorded at the three measuring points varies between $20.8 \% \div 21 \%$ (Table 1 ).

Table no. 1 Volume $\mathrm{O}_{2} \%$ recorded in the three measurement points.

\begin{tabular}{|l|c|c|c|}
\hline Parameter & $\begin{array}{c}\text { P1 } \\
\text { (Warehouse raw } \\
\text { materials) }\end{array}$ & $\begin{array}{c}\text { P2 } \\
\text { (production and sales of bakery } \\
\text { products) }\end{array}$ & $\begin{array}{c}\text { P3 } \\
\text { (manufacturing and } \\
\text { selling patries) }\end{array}$ \\
\hline $\mathrm{O}_{2}, \%$ & 21 & 20.9 & 20.8 \\
\hline
\end{tabular}

Regarding to the parameter the particulate matter (wheat flour), the values recorded at the three measuring points fall within the emission limit values (VLE) imposed by GD 1218/2006. Thus, at the point P1 (stock of raw materials), the recorded value was $0.300 \mathrm{mg} / \mathrm{m}^{3}$ (Figure 2), which is a VLE value of $0.5 \mathrm{mg} / \mathrm{m}^{3}$. 


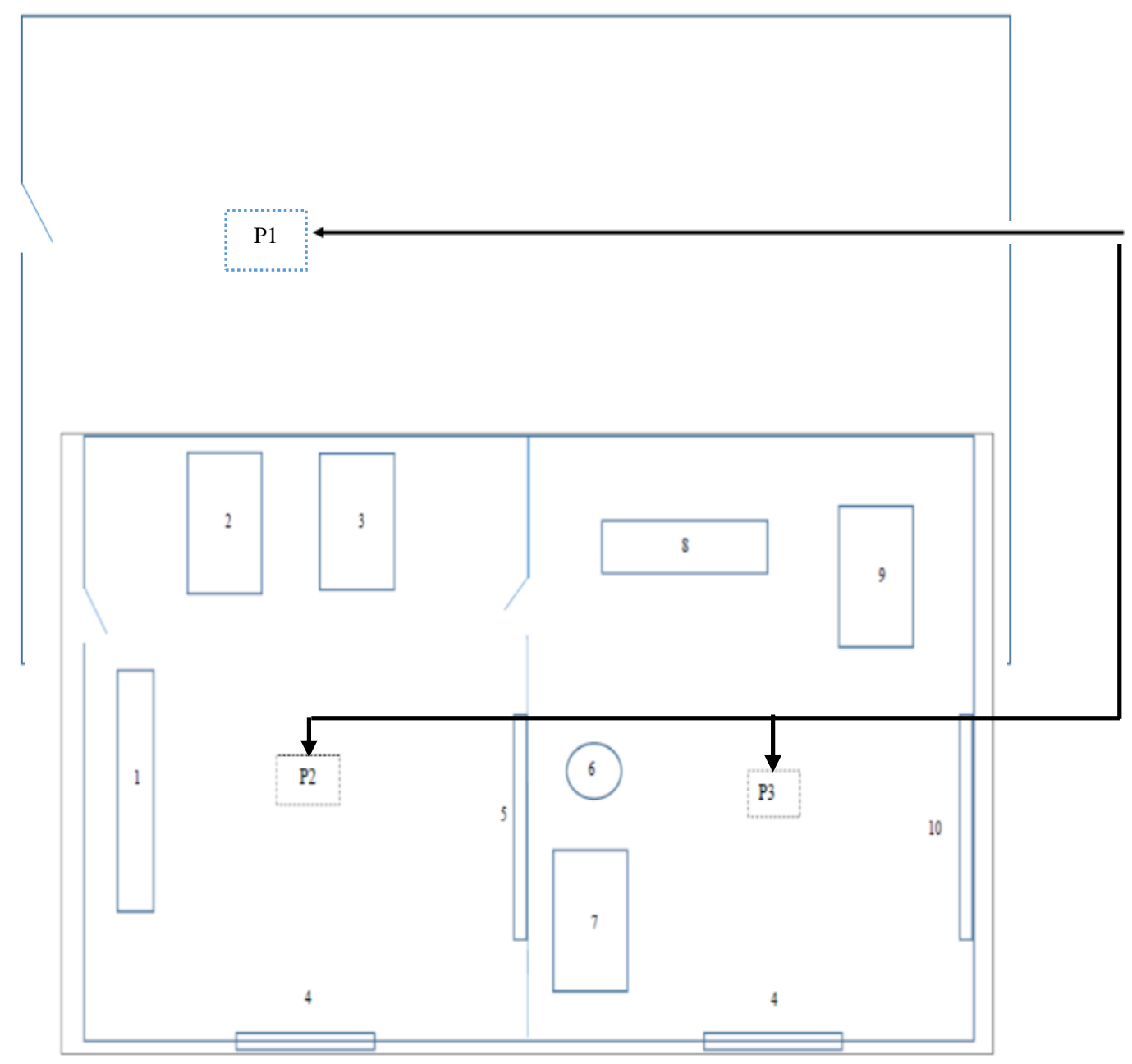

Fig. 1. Scheme of location of the sampling point in working areas of the raw materials warehouse:

0 level (basement); P1 - point sampling; b. level 1 (ground floor): 1 - modeling; 2- oven; 3 - fermenting; 4- sales area; 5 - shelves; 6 - pot boiling; 7 - oven; 8 - meal modeling; 9 - oven; 10 - shelves; P2, P3 - point sampling.

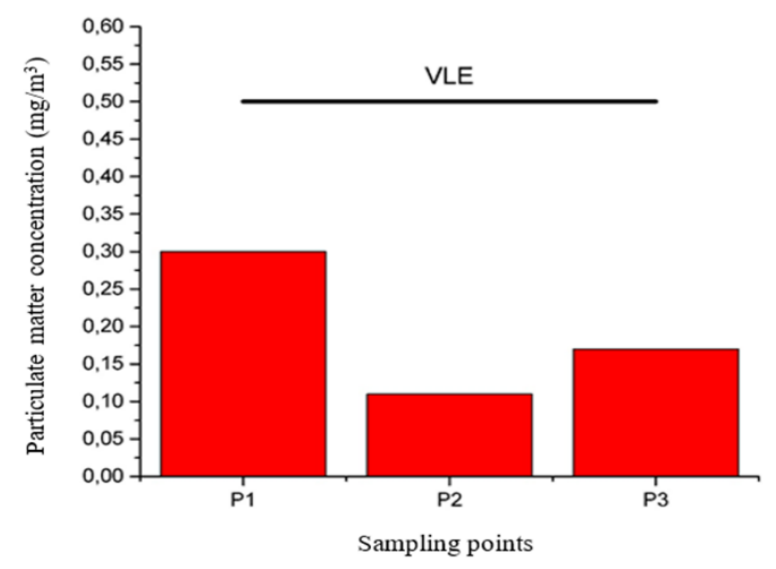

Fig. 2. Variation parameter particulate matter recorded in the three measurement points.

At point P2 (production and sales of bakery products) the value recorded was $0.11 \mathrm{mg} / \mathrm{m}^{3}$ (Figure 2) which is well below the VLE of $0.5 \mathrm{mg} / \mathrm{m}^{3}$. For point P3 (production and sales of pastry products) the value recorded for the 
particulate matter (wheat flour) parameter was $0.17 \mathrm{mg} / \mathrm{m}^{3}$ (Figure 2) which falls within the VLE required by GD $1218 / 2006$ [2], respectively $0.5 \mathrm{mg} / \mathrm{m}^{3}$.

Regarding the humidity and temperature parameters, the measured values for these parameters varies in the range $\left(22.1^{0} \mathrm{C} \div 29.2^{0} \mathrm{C}\right)$ in the case of the temperature, respectively $(47 \% \div 53 \%)$ in the case of humidity. The highest temperature and $29.2{ }^{\circ} \mathrm{C}$ temperatures were recorded at point $\mathrm{P} 3$ (production and sales of pastry products), temperature, combined with a $47 \%$ humidity (Table 2). The recorded humidity values fall within the thermal comfort range. In terms of temperature, values exceeding $22^{\circ} \mathrm{C}$ are considered outside the thermal comfort range.

Table 2. The temperature and humidity recorded in the three measurement points.

\begin{tabular}{|l|c|c|c|}
\hline \multicolumn{1}{|c|}{ Parameter } & $\begin{array}{c}\mathrm{P} 1 \\
\text { (Warehouse raw materials) }\end{array}$ & $\begin{array}{c}\mathrm{P} 2 \\
\text { (production and sales of } \\
\text { bakery products) }\end{array}$ & $\begin{array}{c}\text { P3 } \\
\text { (manufacturing and selling } \\
\text { patries) }\end{array}$ \\
\hline $\mathrm{T},{ }^{0} \mathrm{C}$ & 22.1 & 24 & 29.2 \\
\hline $\mathrm{U}, \%$ & 48 & 53 & 47 \\
\hline
\end{tabular}

With respect to VOCs, the values recorded during the measurements at the three measuring points fall within the range $(0.8 \mathrm{ppm} \div 21.1 \mathrm{ppm})$ values that fall within the $100 \mathrm{ppm}$ emission limit imposed by GD 1218/2006 [2], with subsequent modifications and completions (Figure 3). Emissions of VOCs identified during measurements may come from equipment in the workspace, cleaning materials used.

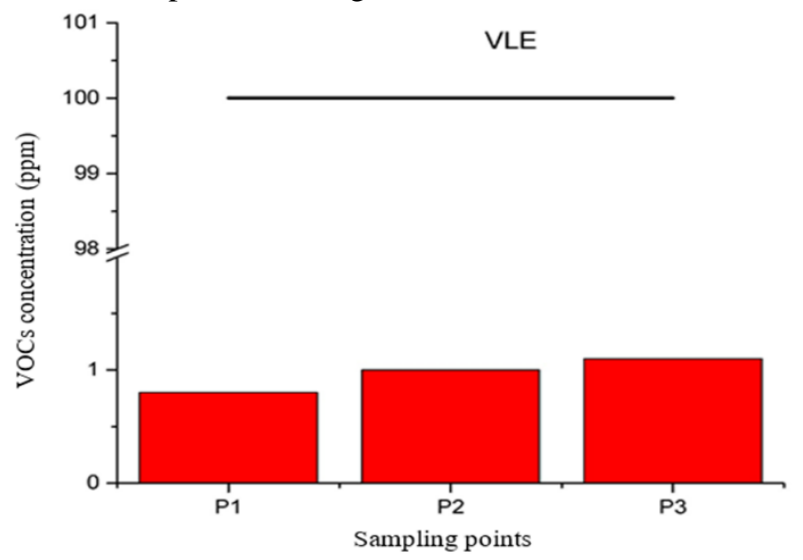

Fig. 3. Variation VOC values identified in measurement points.

\section{CONCLUSION}

Values measured parameters fall within the emission limit values imposed by GD 1218/2006 as amended and supplemented, which indicates a nontoxic work environment for employees. As regards the parameter values recorded for temperature where the recorded values indicate a variation in temperature range $\left(22.1^{0} \mathrm{C} \div 29.2^{\circ} \mathrm{C}\right)$, being careful to point P3 (producing and selling pastries) where it's found the highest temperature value (Table 2) and in accordance with the requirements of OU 99/2000 [13], we recommend the following actions:

- $\quad$ to better working conditions:

- reducing the intensity and pace of physical activity;

- alternating dynamic and static effort;

- alternating working periods with rest periods in shady places with air currents.

- $\quad$ maintaining the health of employees.

$\circ$ providing personal protective equipment;

- shower insurance.

AKNOWLEDGEMENTS: The work has been funded by contract research no. 17/2015 "Study regarding determination of professional workplaces hazards in the SC Nadenka SRL, Str. 9 mai, Bacau".

\section{References:}

[1] Legea 319/2006, cu modificarile și completarile ulterioare, a securitatii si sanatatii in munca. 
[2] HG 1.218/2006, cu modificarile și completarile ulterioare, privind stabilirea cerintelor minime de securitate si sanatate in munca pentru asigurarea protectiei lucratorilor impotriva riscurilor legate de prezenţa agenţilor chimici. [3] HG 1.091/2006 privind cerintele minime de securitate și sanatate pentru locul de munca.

[4] Friptuleac, G., Meşina, V., Sanatatea si factorii ocupaţionali, Ed. Poligrafică Bons Offices, Chișinau, 2006.

[5] Silva, E. C., Accidents and the technology, Journal of Loss Prevention in the Process Industries, vol. 49, part B, 2017, p. 319-325.

[6] Silva, E.C., Why are major accidents still occurring?, Process Safety Progress, New York, 2015, p. $253-257$.

[7] García-Herrero, S., Mariscal, M.A., García-Rodríguez, J., Ritzel, D.O., Working conditions, psychological / physical symptoms and occupational accidents. Bayesian network models, Safety Science, vol. 50, 2012, p. 1760 1774

[8] Suárez Sánchez, A., Riesgo Fernández, P., Sánchez Lasheras, F., Cos Juez, F.J., García Nieto, P.J., Prediction of work-related accidents according to working conditions using support vector machines, Applied Mathematics and Computation, vol. 218, 2011, p. 3539-3552.

[9] Holcroft, A.C., Punnett, L., Work environment risk factors for injuries in wood processing, Journal of Safety Research, vol. 40, 2009, p. 247-255.

[10] Khadem-Rezaiyan, M., Afshari, R.M., Carbon monoxide poisoning in Northeast of Iran, Journal of Forensic and Legal Medicine, vol. 41, 2016, p. 1 - 4.

[11] Huang, C.H., Lin, P.Y., Influence of spatial layout on airflow field and particle distribution on the workspace of a factory, Building and Environment, vol. 71, 2007, p. 212-222.

[12] Rim, D., Novoselac, A., Transport of particulate and gaseous pollutants in the vicinity of a human body, Building and Environment, vol. 44, 2009, p. 1840-1849.

[13] OUG 99/2000, privind masurile ce pot fi aplicate in perioadele cu temperaturi extreme pentru protecția persoanelor incadrate in munca. 